\title{
Age-Friendly Rural Areas. The Challenges of Measurement and Evaluation in Czech Older Adults ${ }^{1}$
}

\author{
Lucie Vidovićová
}

\begin{abstract}
This article presents a study on the application of the age-friendly measurement index in the context of rural areas in the Czech Republic. Small cities and rural settlements comprise the great majority of municipalities and face considerable ageing of their populations. The age-friendliness concept expresses how and to what extent communities offer a supportive environment that enables residents to grow older actively within their families, neighbourhoods, and civil society together with extensive opportunities for participation in the community. Amenities related to public spaces and transportation are key aspects supporting these goals. The proposed measure uses the survey method to describe the perceptions of these aspects by older inhabitants in settlements of various degrees of rurality. The more rural areas, as expected, show fewer positive evaluations of outdoors amenities and transportation; however, this does not influence outcome variables, such as reported happiness, subjective health or overall satisfaction. Discussion of the content of the age-friendly concept in rural contexts is provided.
\end{abstract}

KEY WORDS rural areas; age-friendliness; active ageing; measurement; methods; Czech Republic

\section{Introduction}

As people grow older, their action radius as well as sense of belonging tend to shrink to smaller geographical areas and places (Webber, Porter and Menec 2010; UNECE 2018). Ageing, however natural, active, productive and successful, decreases the ability, agency, strength, power and sometimes pure willingness to move or change living environment as people decide (or are left) to age in place, often regardless of the quality of the place itself. For many people in the Czech Republic, similarly to other places in Europe, the place is either big cities or rural communities, as these two types of settlements have the highest shares of older population. The situation will change in the near future, as the smaller and mid-size cities are "catching up" in regard to the pace of population ageing, but for the time being the smallest rural areas ( $<199$ inhabitants) and the biggest cities $(>50,000$ inhabitants) have up to 3 percentage points higher share of people aged 65 and older, compared with other

Sociální studia / Social Studies 1/2018. Pp. 25-43. ISSN 1214-813X.

1 The writing of this article and data collection were supported by the Czech Scientific Agency project "Rural Ageing: Unanswered Questions in Environmental Gerontology" (2016-2018) (Grant No. 16-20873S). 
types of settlements (CZSO 2018). While maybe not big in a mathematical sense, having every fifth person in senior age brackets in small settlements make older adults an important category in various policy making endeavours. To craft policies that would ensure not only that people age in place, but age in a good place, the worldwide initiative of Age-Friendly Cities and Communities (AFCC) was established by the World Health Organisation in 2005 (Warth 2016) and grew to become a strong and popular movement in the last decade (Fitzgerald and Caro 2014; Buffel, Phillipson and Scharff 2012). Nowadays we are witnessing a widespread interest in the idea of age-friendliness far from its original use as "just" support for active ageing in the city. The WHO talks about creating an age-friendly world (WHO 2007).

As the idea of AFCC gains momentum, so does the need to somehow capture whether various endeavours, actions and policy frameworks under the age-friendliness umbrella deliver the promised results and whether they have a positive influence on the quality of life of older people and deliver desirable outcomes. The interest is both methodological, i.e. how to translate the very idea of age-friendliness into measurable indicators, and practical, i.e. how to produce a tool that will help cities and communities to monitor their situation and progress. However, until now very few studies have paid attention to the diversity of contexts where age-friendliness could/should be assessed. Studies are especially scarce in the context of rural communities. Therefore, the leading questions for this paper are: can the concept of age-friendliness be easily adapted to rural contexts? Can we measure age-friendliness by use of survey methods, and what will the outcomes teach us about ageing in rural communities? In order to answer these questions, we will first briefly discuss the leading ideas behind the concept of age-friendliness, as well as some lines of critique; we then provide a brief overview of the empirical tools for the measuring of age-friendliness available so far. After this introduction, we provide a few notes on the local context of Czech countryside, both past and present, to set the scene. The empirical part sets off with detailed description of the methodology we used in evaluating the age-friendliness of the rural areas and provides information about the sample used. In the results section, the construction of the age-friendly index for outdoors and transportation in rural areas is described, and in the discussion its limitations and points for further development are suggested.

In this article, we are building on our previous work on age-friendliness baseline measurement, evaluation, and ranking of the fourteen biggest cities in the Czech Republic, described in detail elsewhere (Vidovićová et al. 2013; Vidovićová 2017). As will be explained in more detail below, we are using the same methodological processes and producing similar outcomes; however, in this case the measure of age-friendliness in heterogenous rural contexts presents specific challenges.

This article is a borderline piece, somewhere between an overview, research report and methodological note, in disciplines including, but not limited to, social gerontology, environmental gerontology, human geography, social policy, architecture, and spatial planning, as well as practical in terms of examining local governance and representation of older people's rights to public space. We therefore are not able to dive in depth into all the various concepts and features we are building upon here due to limited space, but we provide references for further study. 


\section{Defining age-friendly city and community}

The original definition understands the age-friendly city as an "inclusive and accessible community environment that optimises opportunities for health, participation and security for all people in order that quality of life and dignity are ensured as people age" (WHO 2007). Later, Fitzgerald and Caro (2014) proposed a definition according to which the "age-friendly city and community offers a supportive environment that enables residents to grow older actively within their families, neighbourhoods, and civil society and offers extensive opportunities for their participation in the community" (Fitzgerald and Caro 2014: 2).

The age-friendly concept has been built on the foundation of the powerful idea of "active ageing". The definition proposed by WHO in 2002 sees active ageing as "the process of optimizing opportunities for health, participation and security in order to enhance quality of life as people age. It allows people to realize their potential for physical, social, and mental wellbeing throughout the life course and to participate in society according to their needs, desires and capacities, while providing them with adequate protection, security and care when they require assistance" (WHO 2002: 12). Proponents understand both active ageing and age-friendliness as universal goods, noble goals and win-win situations:

Because active ageing is a lifelong process, an age-friendly city is not just "elderly friendly". Barrier-free buildings and streets enhance the mobility and independence of people with disabilities, young as well as old. Secure neighbourhoods allow children, younger women and older people to venture outside in confidence to participate in physically active leisure and in social activities. Families experience less stress when their older members have the community support and health services they need. The whole community benefits from the participation of older people in volunteer or paid work. Finally, the local economy profits from the patronage of older adult consumers. The operative word in age-friendly social and physical urban settings is enablement. (WHO 2007: 6)

The Age-Friendly Cities and Communities (AFCC) guide highlights eight domains that cities and communities can address to better adapt their structures and services to the needs of older people: the built environment, transport, housing, social participation, respect and social inclusion, civic participation and employment, communication, and community support and health services. As such it is led by three core principles: inclusion, participation and safety (cf. Moulaert and Garon 2016 and Buffel, Handler and Phillipson 2018 for the detailed history and the rationale behind development of the AFCC).

While these domains are not ranked in importance whatsoever, to date the greatest amount of attention from academia as well as policymakers has been devoted to "age-friendly environments", looking at how place, as a socio-spatial phenomenon, can shape older adults' lives, and how can it serve to enhance the quality of life and protect against various types of exclusion in later life. In short, it is said that if an older person can leave his or her house comfortably and safely, s/he can travel the whole world. This saying reflects that there must be a fit between the person's abilities and the qualities of the space and environment which will enable this person to get out of bed, go out the door, and into the neighbourhood and community, to find the services and social relationships s/he needs to have a good life. In this process, qualities such as accessibility, visitability, walkability, and perceived safety 
of the outdoors environment can make the difference, and determine whether people with mobility decline can make those steps. The age friendliness lens should serve as a tool to design, build and evaluate these qualities.

\section{The measurement of age-friendliness}

The WHO guide to using core indicators to measure the age-friendliness of cities (2015) proposes following age-friendly environment outcomes in two areas: accessible physical environment (neighbourhood walkability, accessibility of public spaces and buildings, accessibility of public transportation vehicles, accessibility of public transportation stops, affordability of housing) and inclusive social environment (positive social attitudes toward older people, engagement in volunteer activity, engagement in paid employment, engagement in socio-cultural activity, participation in local decision-making, availability of information, availability of health and social services, and economic security) (WHO 2015: 27). For each of these domains, suggested definitions of the indicators are given together with suggested data sources (e.g. administrative data from the local transit authority or city planning department on the proportion of housing within walking distance [500 m] of a public transportation stop for the "accessibility of public transportation stop" indicator) and the inclusion of self-reported data (e.g. surveys of older residents) is suggested together with other alternative indicators (e.g. additional indicators to take into consideration the safety and quality of the route to the transportation stop). While the makeup of the indicators is clearly urban, the definition process and the logic of building up an indicator set could be used for other territorial contexts as well. Kano, Rosenberg and Dalton (2018) summarise the following six arguments for the importance and usefulness of AFCC indicators: establishing a common understanding about a new concept (operationalisation as a way of defining the content), setting a goal and targets, monitoring change over time as relevant interventions are implemented, fostering political and social commitment and accountability, and benchmarking.

In social gerontology, the research into the environmental determinants of quality of life in later life is abundant (Menec and Nowicki 2014; Spina and Menec 2015; Burton, Mitchell and Stride 2011; Wight, Ko and Aneshensel 2011; Bowling and Stafford 2007; Beard et al. 2009; Bramson, Pretty and Chipuer 2002; cf. also the overview by Levasseur et al. 2015), but studies assessing the actual physical environment as a subject are much rarer (cf. Moulaert and Garon 2016; Feldman and Oberlin 2003), especially those using a quantitative approach (Gobbens and van Assen 2018; Kano, Rosenberg and Dalton 2018; Wong, Chau, Cheung, Phillips and Woo 2015; Age-friendly Cities 2009), and those within the context of environmental gerontology (Wahl and Weisman 2003; Kendig 2003). As the AFCC was primarily defined as an urban concept, research on age-friendly rural communities is somewhat scarcer, with the notable exception of work by Keating, Eales and Phillips (2013), Lui et al. (2009), Menec and Nowicki (2014), and Menec, Hutton and Newall (2015).

It should also be noted that the measurement of age friendliness can shape of a list of suggested features where the presence or non-presence of a given amenity or service is noted by the city/community officials. This checklist for policy makers serves the purpose 
of reviewing existing infrastructure and policies and defining possible directions for improvement of policies or new investments. In this approach, it is believed that the suggested items do have the consensual quality and are desirable for all users. An interesting example of this approach can be seen in Australia (Brasher 2018), where the importance of the items is evaluated, so that only items considered important for the given community are considered, recognising different needs in different contexts. In some respects, this approach may be vulnerable to mediocre solutions, where the goals are undermined by factors such as fiscal/budgetary restrictions, (absence of) political will or knowledge, or by internalised or even openly ageistic values and attitudes held by reviewers/evaluators, policy makers and planners.

From the notes above, we can see that there are several methods to measure the state of the age friendliness of a given city or community, but the benchmarking and empirical measurement of progress are scarcer, although policymakers are determined to find out "what works" and how to improve the impact. The sociological methods here can be very helpful in providing instruments which will measure the baseline, track the intervention and, by repeating the measurement after the intervention, measure the effect of the intervention. However, the social world and the living organism of a community or a city is far from an ideal environment for controlled experiments, wherein all, or at least almost all, intervening factors should be known and controlled for. Yet, to know whether something "works" and actually results in satisfaction, increases quality of life, and supports dignity as people age, is vital.

In an ideal world, a cycle of continuous improvement would consist of mechanisms for involving older people, followed by a baseline assessment, translated to a city/ community-wide action plan, followed by the finding and evaluating of indicators to monitor progress, and then going back to the older people involved to start a new cycle. The cyclical method assumes that there is no a priori desirable end, only a desirable direction toward achieving defined goals, as there seems to always be room for improvement. The measurement of AFCC goals achievement has always included cooperation from older residents themselves; it has to be co-produced and co-researched (Buffel 2018) with them and by them. In this sense it is participatory by default. The majority of the available measurement and evaluation methods available for both city and rural communities are small scale projects, using qualitative or mixed methods approaches to survey opinions or relay statistical objective data (WHO 2015).

In our study presented below, we were relying on our own set of indicators from self-reported data defined in the previous study of the fourteen biggest Czech cities. This urban project was commissioned in 2011 when the WHO core indicators were not yet available. In the recent study, the preference was to produce data which would be at least to some extent comparable within the nation state, as we were looking for answers as to whether the situation we have seen in the cities is unique to the experience of living in urban centres, or one of ageing per se, and therefore shared across different environments. We were happy to see that we were able to come up with very similar set of indicators, as was later proposed in the AFCC Guide (WHO 2015), proving the consistency of the concepts covered in the age-friendly framework. 


\section{A critique}

The concept of age-friendliness is an "easy match" to its ancestor "active ageing" in terms of the frequency of its use in the policymaking and academic debates, but also in rising critiques. The concept has been under scrutiny for its relative vagueness and for overstressing the role and the neoliberal burden of responsibility on the agentic social actor, who is expected to be active, engaged, and socially and economically productive, including the requirement that older residents be involved in the co-production of age friendly places. Another line of critique builds on the geopolitical context, showing that age-friendly initiatives, although being advertised as based on a worldwide network, mainly occur in the developed world (Steels 2015). Similarly, Moulaert and Garon (2016) complain about the hegemony of the use of the English language, which may lead to misinterpretations of some key AFCC concepts. For example, in non-English languages and cultural contexts the term "community" may have different meanings and connotations and, most importantly, may represent different socio-geographical spaces.

Golant (2014) poses several provocative questions to draw attention to some of the unspoken issues he identifies in the AFCC rhetoric, organisation and programmes. They relate to issues such as (non-) established synergies of AFCC with other similar initiatives and policies; the susceptibility of AFCC programmes to "the whims of governments' or other organizations" priorities"; and the dependence of the programmes on strong leadership, which may be lacking in communities featuring older people with unmet needs. He further criticises the unclear individual outcomes and goals; vague definitions of the target population (Are age-friendly communities intended to help healthy older people live more meaningful lives or to help the most frail older people age safely in place?) (cf. Lindenberg and Westendorp 2015); lack of information on how these programmes are handled; and, above all, limited knowledge whether they actually work. Golant (2014: 15) makes the urgent call that age-friendly community-based programs must respond to criticism that their agendas are over-ambitious. Lastly and most importantly, we need more evidence-based research assessments to determine whether these programs are working and benefiting the targeted subgroups of older people. We require resident-level data that report on how these initiatives have improved the physical or psychological well-being of older people, and we need community-based data that identify the ways in which local and provincial or state governments have realized social, health or fiscal benefits.

In this request he is not alone. The voices move from questions such as "What is an ideal city/community for older people?" to the question of "How age-friendly are cities and communities?", which have recently been coming from both academia (Buffel, Phillipson and Scharf 2012; Buffel and Phillipson 2018) and policy-oriented international platforms, such as the International Federation on Ageing (2015). In the following parts of the article we will show one of the available instruments that makes this goal closer to reach.

\section{Rural areas in the Czech Republic}

Before sharing our methods and results we should include few notes on the specificities of Czech rural areas. Despite the dominant public and media discourses, wherein 
the countryside is often labelled as uniform, lagging behind, boring, depopulating, ageing, poor, and deprived of services (cf. Plüschke-Altof 2016; Bernard and Šimon 2017; Gerritsen et al. 1990), there is no single definition of rurality, or even a single typology of rurality (Stonawska and Vaishar 2018; Pospěch et al. 2014; Petr 2015; Perlín, Kučerová and Kučera 2010; Perlín n.d.), and the available data on the quality of life in rural areas prove these stereotypes rather wrong (cf. Vidovićová 2018; Majerová 2004; Pospěch, Delín and Spěšná 2009; Bernard and Šimon 2017; Vaishar, Vidovićová and Figueiredo 2018).

Among scholars there is a broad consensus that rural areas are very diverse in many respects, such as position within state and regional borders, relative position towards and distance from bigger regional centres, the sociodemographic composition of inhabitants, the dominant sectors of employment (being either in agriculture or outside of the settlement), specific urbanistic features with central squares as pivotal places of cultural and social happenings, density of pavements, number and density of green areas, etc. The houses are predominantly family houses with gardens attached to the backyards, or low-rise buildings. Sociologists traditionally also use the dense social relationships with high levels of social control and solidarity as definitional criteria for distinguishing rural from urban. All these features are touched upon within the age friendly framework and therefore, given this diversity, some indicators based on the physical and social space will be more relevant than others.

From January 2007 till January 2018, the share of the Czech population living in settlements with less than 2000 inhabitants, the threshold often used for the definition of rural (Pospěch, Delín and Spěšná 2009), increased slightly from $26.4 \%$ to $26.9 \%$. The average age was 42 years, which is almost the same as in the three most populated Czech cities combined, but slightly lower than in the smallest settlements with less than 200 inhabitants (43.3 years on average) (CZSO 2018). About $26 \%$ of all Czechs older than 60 years live in this type of municipality (CZSO 2017).

The types of rurality we used in our study were defined by the work of Petr (2015), who proposed his typology of different municipalities based on five composite indicators: share of occupied flats in family houses to all occupied flats; density of inhabitants in built-up areas; share of employment in typical urban employment sectors (e.g. ICT); share of jobs per one economically active person; and number of selected amenities in the municipality (e.g. schools, health care providers, post office, etc.). While this is not the best way to characterise the "quality" of villages, since in the Czech Republic there are relatively big differences between and within the regions at both the NUTS3 and NUTS2 levels, it is still the best approximation we have if we want to look behind the plain size of the place.

In our research, we considered only small towns and rural municipalities, falling into six categories: 1) towns with under 5,000 inhabitants (5\% of our sample);2) transitional municipalities with significant urban features $(11 \%) ; 3)$ other transitional municipalities $(15 \%)$; 4) rural municipalities (45\%); 5) significantly rural municipalities (22\%); and 6) extremely rural municipalities $(1 \%){ }^{2}$ According to Petr (2015), these six types of settlements

It should be noted that in our sampling the extremely rural areas were covered, but underrepresented. More on the rural study can be found in Petrová Kafková, Vidovićová and Wija (2018). 
represent more than $95 \%$ of all Czech municipalities, and $38 \%$ of Czechs live here. Despite the occasional media and political proclamations, the rural areas in the Czech Republic are not depopulating, they are even gaining inhabitants (Bernard and Šimon 2017), but their population is ageing, as is the whole Czech society. So, how age friendly are these different types of rural municipalities? Are they supporting their residents in ageing well?

Table 1: Baseline demography of the rural typology and distribution of rural types within the research sample

\begin{tabular}{|c|c|c|c|c|c|c|c|}
\hline & \multicolumn{2}{|c|}{$\begin{array}{c}\text { Number } \\
\text { of municipalities }\end{array}$} & \multicolumn{2}{|c|}{ Sample } & \multicolumn{3}{|c|}{ Number of inhabitants } \\
\hline & $\begin{array}{l}(1991- \\
2011)\end{array}$ & $\%$ & $\begin{array}{l}\text { Baseline } \\
\%\end{array}$ & $\begin{array}{l}\text { Selected } \\
\%\end{array}$ & 2011 & $\%$ & average \\
\hline Total in CR & 5702 & 100.00 & - & - & 10141553 & 100.00 & 1779 \\
\hline Cities & 323 & 5.66 & - & - & 6500727 & 64.10 & 20126 \\
\hline ...of which cities with -5000 (I.) & 54 & 0.95 & 0.9 & 5 & 190422 & 1.88 & 3526 \\
\hline Transitional municipalities & 455 & 7.98 & 8.4 & 26 & 1026225 & 10.12 & 2255 \\
\hline $\begin{array}{l}\text {...of which with significant } \\
\text { urban features (II.) }\end{array}$ & 167 & 2.93 & 3.1 & 11 & 435534 & 4.29 & 2608 \\
\hline $\begin{array}{l}\text {... of which other transitional } \\
\text { (III.) }\end{array}$ & 288 & 5.05 & 5.3 & 15 & 590691 & 5.82 & 2051 \\
\hline Rural municipalities & 4919 & 86.27 & 90.6 & 69 & 2612736 & 25.76 & 531 \\
\hline ... of which I. category (IV.) & 2133 & 37.41 & 39.2 & 45 & 1759831 & 17.35 & 825 \\
\hline $\begin{array}{l}\text {...of which II. category } \\
\text { (significantly rural) (V.) }\end{array}$ & 2187 & 38.35 & 40.3 & 22 & 757420 & 7.47 & 346 \\
\hline $\begin{array}{l}\text {...of which III. category } \\
\text { (extremely rural) (VI.) }\end{array}$ & 599 & 10.51 & 11.1 & 2 & 95485 & 0.94 & 159 \\
\hline
\end{tabular}

Source: Petr (2015: 81); bigger cities and military areas omitted; translation by the author.

Note: Roman numbers in brackets give the number of the typology used in our analysis.

\section{Method}

As mentioned above, the logic of our work follows from previous work we did in the fourteen biggest cities in the Czech Republic (Vidovićová et al. 2013; Vidovićová 2017). As our data collection in urban areas started in 2011 when there were very limited resources dealing with the measurement of age-friendliness (note the AFCC guide to using core indicators was not available until 2015), and as we aimed at basic levels of comparability of the results, we chose to use a general methodological framework for data collection in the urban areas and also for our rural project with data collection in 2016. Some of the indicators were slightly changed in wording or scope, or left out, to mirror the situation we encountered based on the literature and consultations with experts, as being more relevant to rural areas.

The environment was here defined in terms of both social and physical dimensions. The questionnaire included separate sections on housing, neighbours, mobility, the availability of services, the frequency of economic and social activities, the perception of changes 
in the immediate living environment, and experience with selected aspects of spatial ageism. By collecting the views of older people living in dynamically changing areas we simulated the consultation process required in the process of assessing age-friendliness.

In our approach, we took the proposed age-friendly features (goals) as defined in the original AFCC guide (2005) and translated (operationalised) them into statements which could be evaluated either as a truth or non-truth (from the point of view of the respondent/evaluator), using a five point Lickert scale (ranging from fully agree to fully disagree) or by a rating of satisfaction using the school marks scale, which in the Czech educational system ranges from 1 (excellent) to 5 (very poor, unsatisfactory), similarly to marks A to F in Anglo-Saxon

Table 2: Operationalisation of the WHO AFC essential features into indicators used in our survey

\begin{tabular}{|c|c|}
\hline WHO Essential Feature & Indicators \\
\hline \multicolumn{2}{|c|}{ Dimension: Outdoor spaces and buildings } \\
\hline Public areas are clean and pleasant. & $\begin{array}{l}\text { In my neighbourhood there are places for recreation } \\
\text { (parks,....). } \\
\text { The winter maintenance of the streets is bad, I often } \\
\text { have to stay at home. }\end{array}$ \\
\hline $\begin{array}{l}\text { Green spaces and outdoor seating are sufficient } \\
\text { in number, well maintained and safe. }\end{array}$ & $\begin{array}{l}\text { There are pleasant benches in sufficient numbers } \\
\text { around here. } \\
\text { There is enough greenery around here. }\end{array}$ \\
\hline $\begin{array}{l}\text { Pavements are well-maintained, free of obstructions } \\
\text { and reserved for pedestrians. }\end{array}$ & $\begin{array}{l}\text { The majority of the streets in our surroundings have } \\
\text { well maintained pavements. (fully agree) }\end{array}$ \\
\hline $\begin{array}{l}\text { Pedestrian crossings are sufficient in number } \\
\text { and safe for people with different levels and types } \\
\text { of disability, with non-slip markings, visual and audio } \\
\text { cues and adequate crossing times. }\end{array}$ & $\begin{array}{l}\text { In our streets there are enough pedestrian crossings, } \\
\text { so I can safely cross the road. } \\
\text { (fully agree) }\end{array}$ \\
\hline \multirow{2}{*}{$\begin{array}{l}\text { Outdoor safety is promoted by good street lighting, } \\
\text { police patrols and community education. }\end{array}$} & $\begin{array}{l}\text { The streets are well lit during the night. } \\
\text { (fully agree) }\end{array}$ \\
\hline & Evaluation of the work of local police (A) \\
\hline Services are situated together and are accessible. & $\begin{array}{l}\text { Most shops and services that I require are here in my } \\
\text { neighbourhood. (yes) } \\
\text { Evaluation of the shops \& services availability. (A) }\end{array}$ \\
\hline $\begin{array}{l}\text { Public toilets outdoors and indoors are sufficient } \\
\text { in number, clean, well-maintained and accessible. }\end{array}$ & (not used in rural survey) \\
\hline \multicolumn{2}{|c|}{ Dimension: Transportation } \\
\hline $\begin{array}{l}\text { Public transport costs are consistent, clearly } \\
\text { displayed and affordable. }\end{array}$ & \multirow{3}{*}{$\begin{array}{l}\text { Taking in to account my current needs, public } \\
\text { transport is well organised. } \\
\text { The time tables are usually clearly readable. } \\
\text { The public transportation vehicles are usually easily } \\
\text { accessible. } \\
\text { The transport stop is close to my home. } \\
\text { (fully agree) }\end{array}$} \\
\hline $\begin{array}{l}\text { Vehicles are clean, well-maintained, accessible, } \\
\text { not overcrowded and have priority seating that } \\
\text { is respected. }\end{array}$ & \\
\hline $\begin{array}{l}\text { Transport stops and stations are conveniently } \\
\text { located, accessible, safe, clean, well-lit } \\
\text { and well-marked, with adequate seating and shelter. }\end{array}$ & \\
\hline $\begin{array}{l}\text { Parking and drop-off areas are safe, sufficient } \\
\text { in number and conveniently located. }\end{array}$ & (not used in rural survey) \\
\hline
\end{tabular}

Source: WHO (2007) and author's operationalisations 
cultural settings. We then used these reported values to produce a simple score for each of the essential feature dimensions, usually the share of highly satisfied older respondents, and produced the simple average of the evaluations for all the domains evaluated. For our study of the cities, this was translated into a ranking before the mathematical operation of averaging was done. This procedure helps to make the benchmarking easier to follow as only one numerical ranking from 1 (the best) to 14 (the worst) per indicator was given to each city. On the other hand, this operation covers the distance and the size of the difference between each municipality, as some differences can be as small as a few percentage points, while others can be more substantial, pointing to greater need for improvement in a given feature.

For this exercise we have chosen to analyse only two dimensions out of eight in the AFCC framework: transportation and outdoor spaces and buildings. This measurement here, therefore, accounts for only a selection of amenities, presence of which is considered crucial for place age-friendliness. Table 2 gives an overview of how each WHO AFCC essential feature was operationalised into the item used in the survey for evaluation of the immediate living environment of older residents living in various types of rural municipalities or very small towns (less than 5,000 inhabitants).

The data collection was realised as a part of a project called "Rural Ageing: Unanswered Questions in Environmental Gerontology (2016-2018; supported by Czech Science Foundation Grant No. 16-20873S). The data were collected from a representative sample of the older rural population in the Czech Republic and using the CAPI method (Computer Assisted Personal Interviews) by a subcontracted agency. In total, we obtained 1,235 completed questionnaires from face-to-face interviews with people aged 60 years and above in rural populations. Only the non-institutionalised population was involved. The representative sample was selected using quotas for age, sex, education, region (NUTS3), and predefined rurality type, and was weighted. For the analysis, IBM SPSS (version 24) software was used. Selected characteristics of the sample are given in Table 3.

Overall, the sample consists of long-term residents living in the researched areas. Most of them were already retired, in relatively good health, and for the most part also living in a partnership; $12 \%$ lived in households with three or more members.

\section{Results}

The results showing the age-friendliness (AF) of various rural areas in the Czech Republic are given in Table 4 and Figure 1. As opposed to measuring AF in the cities, where each city was represented by a substantial number of respondents, similar measurement in the rural areas cannot be used to rank each single municipality using the nation-wide representative sample. Too few cases were collected per each unit to allow for this type of result. Instead, the typology is used as the main tool for sorting the results. Alternatively, the objective size of the municipality, or subjective self-evaluation of the type of the settlement, can be used. In our dataset, all three measures have relatively close fit, but we decided to stick with the typology, which reflects more than size simply in terms of the number of inhabitants by including some urbanist and economic features. By this we may, at least to some extent, distinguish the levels of opportunity available in the municipalities. 
Table 3: Descriptive summary of respondents' characteristics (in \%)

\begin{tabular}{|c|c|}
\hline Male & 44 \\
\hline Female & 56 \\
\hline \multicolumn{2}{|l|}{ Age: } \\
\hline $60-69$ & 55 \\
\hline 70-79 & 29 \\
\hline $80+$ & 16 \\
\hline \multicolumn{2}{|l|}{ Education: } \\
\hline Primary & 35 \\
\hline Secondary without graduation certificate ("maturita") & 41 \\
\hline Secondary with certificate & 19 \\
\hline Higher & 5 \\
\hline \multicolumn{2}{|l|}{ Objective place attachment: } \\
\hline Born in the municipality & 62 \\
\hline Moved in & 38 \\
\hline - moved in after 1989 & 30 \\
\hline - moved in after 2010 & 6 \\
\hline Living in the area for 12 months of the year & 96 \\
\hline \multicolumn{2}{|l|}{ Additional characteristics: } \\
\hline Having a partner & 66 \\
\hline Working for pay & 23 \\
\hline Using a walking aid & 26 \\
\hline
\end{tabular}

Source: Rural Ageing Survey (2016) and the author's calculations

As we examine the aspects covered in the index noted in Table 4, we find that very rural municipalities report transportation stops close to home, probably given their small size, which is also a positive feature in the smaller towns, and this share is fully comparable with the shares recorded in the urban sample in 2011. In other types of municipalities, however, only about $30 \%$ of respondents find the proximity of public transport stops highly satisfactory. Also, some features of public transportation do not seem to be very age friendly, such as "the time tables not being well maintained", and "the vehicles are not easily accessible". As would be expected, the proximity of other important services and shops decreases as the level of rurality rises. However, the shares for smaller towns (79\%) are above the urban sample (67 \%) and some cities (e.g. Karlovy Vary, Ústí and Labem) even reported the same levels that we find in rural and significantly rural municipalities. On the other hand, there are important positive features related to high levels of rurality, such as being imbedded in greenery - around $60 \%$ (only $23 \%$ of Czech urban seniors report this), or having a pleasant view from the window (26\% on average; $60 \%$ in extremely rural municipalities; $16 \%$ in the urban sample). On the other hand, it should be also noted that not all rural areas are all green and not all houses have a pleasant view of the rural idyll. 
Table 4: The construction of the age-friendliness index and ranking, by the type of rurality

\begin{tabular}{|c|c|c|c|c|c|c|c|c|}
\hline & & I. & II. & III. & IV. & V. & VI. & Total \\
\hline $\begin{array}{l}\text { Q11.1: The transport stop is close } \\
\text { to my home. }\end{array}$ & Fully agree & 50 & 33 & 34 & 25 & 30 & 54 & 30 \\
\hline $\begin{array}{l}\text { Q1 1.3: The timetables are usually } \\
\text { clearly readable. }\end{array}$ & Fully agree & 52 & 27 & 25 & 20 & 23 & 30 & 24 \\
\hline $\begin{array}{l}\text { Q11.4: The vehicles are usually easily } \\
\text { accessible. }\end{array}$ & Fully agree & 46 & 18 & 20 & 19 & 24 & 36 & 22 \\
\hline $\begin{array}{l}\text { Q11.2: Taking into account my } \\
\text { current needs, public transport is well } \\
\text { organised. }\end{array}$ & Fully agree & 51 & 28 & 22 & 20 & 19 & 8 & 23 \\
\hline $\begin{array}{l}\text { Q33.d: There is enough greenery } \\
\text { around here. }\end{array}$ & Fully agree & 61 & 56 & 61 & 60 & 64 & 73 & 61 \\
\hline $\begin{array}{l}\text { Q33.m: There are pleasant benches } \\
\text { in sufficient numbers. }\end{array}$ & Fully agree & 37 & 28 & 29 & 24 & 16 & 7 & 24 \\
\hline $\begin{array}{l}\text { Q42.a: The majority of the streets } \\
\text { are well maintained, safe for older } \\
\text { people. }\end{array}$ & Fully agree & 28 & 31 & 28 & 18 & 19 & 25 & 22 \\
\hline $\begin{array}{l}\text { Q42.b: In my neighbourhood there } \\
\text { are places for recreation (parks,....). }\end{array}$ & Fully agree & 37 & 42 & 34 & 30 & 22 & 23 & 31 \\
\hline $\begin{array}{l}\text { Q42.j: In our streets there are enough } \\
\text { pedestrian crossings, so I can safely } \\
\text { cross. }\end{array}$ & Fully agree & 9 & 22 & 14 & 9 & 6 & 6 & 11 \\
\hline $\begin{array}{l}\text { Q42.o: The streets are well lit during } \\
\text { the night. }\end{array}$ & Fully agree & 28 & 42 & 27 & 29 & 22 & 25 & 28 \\
\hline $\begin{array}{l}\text { Q42.U: Poor winter maintenance, } \\
\text { I often have to stay "locked" at } \\
\text { home. }\end{array}$ & $\begin{array}{l}\text { Fully } \\
\text { disagree }\end{array}$ & 37 & 23 & 29 & 31 & 31 & 40 & 30 \\
\hline $\begin{array}{l}\text { Q39: Most important services } \\
\text { and shops are here in my } \\
\text { neighbourhood. }\end{array}$ & Yes & 79 & 57 & 55 & 38 & 33 & 13 & 44 \\
\hline $\begin{array}{l}\text { Q42.t: I have a nice view from my } \\
\text { window. }\end{array}$ & Fully agree & 26 & 28 & 16 & 26 & 28 & 60 & 26 \\
\hline $\begin{array}{l}\text { QR8.1: general aesthetic (school } \\
\text { marks A - F) }\end{array}$ & A & 45 & 30 & 26 & 30 & 36 & 29 & 31 \\
\hline QR8.2: work of the local government & A & 14 & 26 & 18 & 22 & 24 & 20 & 22 \\
\hline QR8.3: relationship with neighbours & A & 29 & 18 & 22 & 28 & 31 & 20 & 26 \\
\hline QR8.4: work of the police & A & 23 & 26 & 14 & 14 & 11 & 13 & 15 \\
\hline QR8.5: transportation & A & 36 & 29 & 20 & 17 & 18 & 0 & 20 \\
\hline QR8.6: shops and services & A & 23 & 21 & 15 & 8 & 6 & 0 & 11 \\
\hline \multicolumn{2}{|l|}{ Sum } & 709 & 583 & 509 & 468 & 463 & 483 & 500 \\
\hline \multicolumn{2}{|l|}{ Average } & 37 & 31 & 27 & 25 & 24 & 25 & 26 \\
\hline \multicolumn{2}{|l|}{ Rank } & 1 & 2 & 3 & 5 & 5 & 4 & - \\
\hline
\end{tabular}

Source: Rural Ageing Survey (2016) and author's calculations

Note: Categories of rural areas: I. cities with less than 5,000 inhabitants, II. transitional with urban features, III. other transitional, IV. rural, V. significantly rural, VI. extremely rural. 
In other words, our results confirm that some amenities are expected and missed (or appreciated) only in certain environments, as different environments also usually mean different lifestyles. Although in our case, the differences are not as big as one might expect. At least in part this may be explained by the historical echo of the changes and directive convergence policies the Czech countryside endured.

Figure 1: The ranking of the rural areas on the AFCC outdoors and transportation index

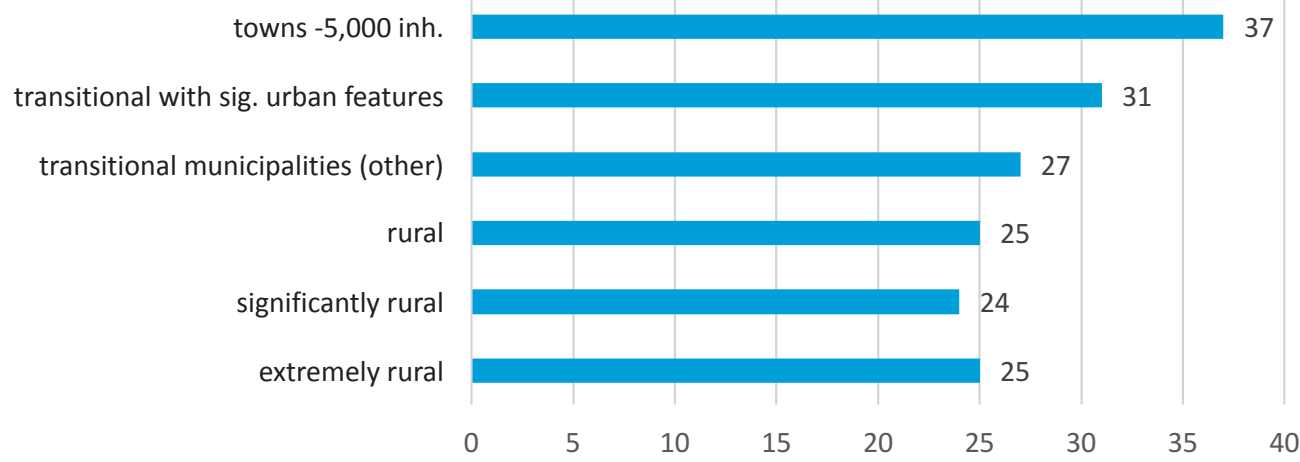

From this perspective, our method and the results obtained are coherent and our findings are in line with what should be expected: small towns and more-like-towns rural municipalities rank considerably higher than truly rural municipalities on the AFCC outdoors and transportation index we have produced.

But does this mean that people in more rural municipalities are less healthy or less satisfied with their environment, social relationships, or life in general? Our data do not support this hypothesis. The type of rural municipality (and bear in mind that it is closely related to the size of the municipality and subjective size, as evaluated by the respondents, as well as the AFCC index) has no statistical association whatsoever with levels of happiness, subjective health, feelings of loneliness, or overall satisfaction with the neighbourhood/ community. Surprisingly enough, that is not what we found in the urban context, where indeed the index did correlate, among others, with measures of loneliness, happiness, and overall satisfaction with the surrounding environment.

\section{Discussion}

The WHO's international age-friendly cities programme started as an "urban" project, where representatives of 33 cities in 22 countries, in the course of series of consultations, produced a checklist to be used by individuals and groups interested in making their cites more age-friendly (WHO 2007). This checklist features a set of statements in eight domains, such as outdoor spaces, transportation, housing, social participation, etc., and is expected to be used as a tool for assessing the cities' strengths and deficiencies. Older people themselves should play a key role in matching their experiences of the everyday reality against 
the "ideal", essential features, such as "public areas are clean and pleasant". The scope of the Age-Friendly Cities guide (WHO 2007) was only recently widened to include non-urban communities and the urban-rural duality - or a continuum, as some will rightly argue - representing an ongoing tension in the age-friendliness debates.

In this article we showcased the adaptation of the age-friendly concept to the measurement of the perceived quality of life of older people living in different types of rural areas. We argued that the shrinkage of the living space of ageing persons calls for increased attention to the quality of the surrounding environment, since it has a direct impact on perception and experience of the social exclusion by space and in space (Walsh 2017), and that the age-friendliness concept has a lot to offer in addressing these issues. We have showed how we can use the survey tool to solicit older people's views, evaluations and attitudes to produce a baseline measurement of the age friendliness of rural places, but we also wish to discuss the limitations of this approach for policy making.

The Czech countryside has undergone rather turbulent changes in last several decades (Pospěch et al. 2014) sharing the development with many other countries in Eastern Europe (Kulcsár and Brown 2017). This long history has had a deep impact on both the living conditions and on the symbolic value of rurality today, and includes the forced resettlement of the German-speaking population after World War II, traumatic collectivisation of the land and stock, erosion of the social order, and bureaucratic top down changes in how the structures of municipalities were organised. In the 1980s the Czech countryside was fully dependent on agriculture and supporting industries, and the need to retain skilled workers was enforced by convergence policies, aimed at implementing urban innovations in housing and consumption in rural areas. Another big change was brought about by developments following the fall of the communist regime in 1989, by which agriculture lost its position as a strategic sector, taking the symbolic importance of rurality down with it. Pospěch et al. (2014) further argue that the lost agricultural monopoly is being replaced by places labelled suburban, peripheral or recreational countryside(s).

These changes happened alongside the ageing of today's older adults (born before 1958) living in these areas. And the changes may have influenced older people's perceptions of the living environment in both negative and positive directions. In a negative sense, the economic turbulences and rising unemployment may have brought financial insecurity resulting in low pension incomes for some, while for others the possibility to work again on private (restituted) lands may have been a resource for wealth in later life. In terms of the physical environment, the decreasing attractiveness of the countryside, especially if located in the inner peripheries on the regions' borders, left some municipalities underserved as both public and private services, such as transportation, post offices, and convenience stores closed down. In other places, on the other hand, the investments from European funds and private investors had a visible impact on the modernisation of infrastructure and improvement of overall aesthetics. These changes were also related to changes in social structures, increasing engagement with and support for the sense of belonging and place attachment, and concepts of crucial importance for later life quality (Burholt 2012). When evaluating the satisfaction of older adults with their current environment, these historical developments may play a crucial role, a phenomenon described as a "biographical contextualisation” by Galčanová (in Vidovićová et al. 2013: 228). 
Simply put, today's conditions and recent changes will be evaluated in the light of the situation(s) encountered earlier in the respondents' lives. Some will remember the dreadful old building which has now been turned into a pleasant community centre, while others will talk about how the old collectivist agricultural buildings are falling apart. In our sample, almost $72 \%$ of respondents talked about changes happening in their surroundings (of which $21 \%$ talked about major changes) and $90 \%$ evaluated them as being positive changes, while only $10 \%$ as negative (in the cities, these shares were $81 \%$ and $19 \%$, respectively). The positive evaluations of changes are slightly more often concentrated in the more rural areas (Gamma coef., 0.120, p. 0.000). This is one of the aspects the AFCC index cannot reveal and which may considerably influence evaluation outcomes.

And there are other drawbacks, as Golant (2014) suggests:

When measuring these outcomes, researchers must also choose between two world views. On the one hand, they can rely on the self-assessments or subjective experiences of older people; alternatively, they can rely on objective indicators of well-being as measured by experts or professionals. Most age-friendly evaluative studies have focused on whether the older users of these programs are satisfied, feel good about their lives or estimate that they can remain independent for longer. Far less frequently, studies have reported on outcomes such as reduced falling rates, lower rehospitalization or nursing home admission rates, better medication management outcomes, fewer emergency room visits, more doctor visits, fewer depressive symptoms, increased volunteerism, reduced difficulties performing everyday activities or evidence of delayed entry of frail older people into nursing homes. (Golant 2014: 14; see also Menec, Newall and Nowicki 2016)

Our measurement provided only the baseline measure of the situation, the level of satisfaction as it is today; however, it seems that for rural areas these indicators either do not discriminate sufficiently between achieved and non-achieved levels of age-friendliness (they are not adequate for measuring the age-friendliness in a rural context), or the different levels of age-friendliness of outdoor qualities and transportation do not have any influence over the desired outcome variables related to older adult lives. In our example above, another shortcoming should be noted, related to the fact that there is not only heterogeneity of places and spatial contexts, but also heterogeneity of older people. Producing one general index and ranking for an "average older person" may conceal some important differences. Therefore, producing reliable AFCC indices for various subgroups of older people, broken down by age group, gender, socioeconomic status, ethnic or racial background, etc., would be desirable.

The indicators can be assigned different weights, as in the Active Ageing Index (Zaidi and Stanton 2015), to help adjust to the variability in the importance each indicator, or set of indicators, can have for different settlements or contexts. However, we need to bear in mind this may interfere with the comparability of results across multiple settings and hinder benchmarking. If applying statistical weights is what is desirable for a particular policy design or evaluation, two separate rankings should be made.

Intuitively, age-friendliness represents a synonym for a pleasant place, but universal design and catering to the needs of all is not an easy task. Obvious conflicts may and do arise in everyday life between pedestrians and those who want to park their cars close to their destinations, between older people with mobility difficulties and working people and students 
during rush hour in public transportation, as we have witnessed in several previous urban studies on older people. During one mapping exercise in Prague, older pedestrians, who have limited peripheral sight or are frail, expressed their fears related to cyclists on the pavements and the shared bicycles parked "in the middle of the street". Yet bicyclists do not feel safe riding on busy roads where cycling paths are missing, so they ride on the pavements instead. The attempt to build a cycling path would clash with the needs of businesses to have at least some parking available for their customers in narrow streets already full of cars and trams, and older residents make use of these businesses, shops and tram stops in their vicinity (Klimešová 2018).

In the rural context, similar clashes of interest may arise. In our follow up qualitative study with older people living in rural areas, a few communication partners complained about new private companies building gated fences around the meadows and forests which before were used as a route or even a destination in their walks in nature. At the same time, these entrepreneurs have brought new opportunities for employment for younger inhabitants, a development highly valued by older residents as well. As has become clear, studying and achieving age-friendliness is much more complex than only producing a single indicator, making an intervention, measuring and evaluating the change, and repeating the process. Even making a simple baseline measurement, as we presented in this article, however easy to do and repeat, and however consistent with the AFCC philosophy, may hide a considerable number of uncertainties. But this is not a call to throw the baby out with the bathwater, or to say that the essential features or indicators measuring age-friendliness are of no use in the rural context. It is just a reminder that, although single figures and quantitative results may be very popular among policy makers, we as a social scientist may want to advocate for methods and techniques which may not be as easy to put into practice (qualitative interviews, etc.), but which may be more valuable in terms of the amount of information they can provide on age-friendliness in rural environments.

\section{References}

Age-friendly Cities Poll Report. 2009. Retrieved September 10, 2015 (http://www.carp.ca/o/pdf/ age-friendly\%20cities\%20poll\%20report\%20web\%20copy.pdf).

BEARD, John, Shanon BLANEY, Magda CERDA, Victoria FRYE, Gina LOVASI, Danielle OMPAD, Andrew RUNDLE and David VLAHOV. 2009. "Neighbourhood Characteristics and Disability in Older Adults." The Journals of Gerontology. Series B, Psychological Sciences and Social Sciences 64(2): 252-257.

BERNARD, Josef and Martin ŠIMON. 2017. "Vnitřní periferie v Česku: Multidimenzionalita sociálního vyloučení ve venkovských oblastech.” [Inner Peripheries in the Czech Republic: The Multidimensional Nature of Social Exclusion in Rural Areas]. Sociologický časopis/Czech Sociological Review 53(1): 3-28.

BOWLING, Anne and Mai STAFFORD. 2007. "How Do Objective and Subjective Assessments of Neighbourhood Influence Social and Physical Functioning in Older Age? Findings from a British Survey of Ageing." Social Science \& Medicine 64(12): 2533-2549.

BRAMSTON, Paul, Grace PRETTY and Heather CHIPUER. 2002. "Unravelling Subjective Quality of Life: An Investigation of Individual and Community Determinants." Social Indicators Research 59(3): 261-274. 
BRASHER, Kathleen. 2018. "Development of an Age-friendly Audit Tool for Rural Communities in Australia." Paper presented at the IFA $14^{\text {th }}$ Global Conference on Ageing, August 8-10, 2018, in Toronto, Canada.

BUFFEL, Tine. 2018. "Social Research and Co-production with Older People: Developing Age-friendly Communities." Journal of Aging Studies 44: 52-60.

BUFFEL, Tine, Sophie HANDLER and Chris PHILLIPSON. 2018. Age-friendly Cities and Communities: A Global Perspective. Policy Press.

BUFFEL, Tine and Chris PHILLIPSON. 2018. "A Manifesto for the Age-friendly Movement: Developing a New Urban Agenda.” Journal of Aging and Social Policy 30(2): 173-192.

BUFFEL, Tine, Chris PHILLIPSON and Thomas SCHARF. 2012. "Ageing in Urban Environments: Developing 'Age-friendly' Cities.” Critical Social Policy 32(4): 597-617.

BURHOLT, Vanessa 2012. "The Dimensionality of 'Place Attachment' for Older People in Rural Areas of South West England and Wales.” Environment and Planning A 44(12): 2901-2921.

BURTON, Elizabeth, Lynne MITCHELL and Chris STRIDE. 2011. "Good Places for Ageing in Place: Development of Objective Built Environment Measures for Investigating Links with Older People's Wellbeing." BMC Public Health 11: 839.

CZSO. Demografická ročenka $\check{C} R$ 2017. [The Statistical Yearbook of the Czech Republic 2017]. 2017. Retrieved August 21, 2018 (https://www.czso.cz/csu/czso/demograficka-rocenkaceske-republiky-2016).

CZSO. "Počet obyvatel v obcích - k 1. 1. 2018." 2018. [The number of inhabitants in municipalities as of 1. 1. 2018]. Retrieved August 21, 2018 (https://www.czso.cz/csu/czso/pocet-obyvatel-v-obcichsee $2 a 5 t x 8 j)$.

FELDMAN, Penny and Mia OBERLINK. 2003. "The AdvantAge Initiative: Developing Community Indicators to Promote the Older People." Family \& Community Health 26(4): 268-274.

FITZGERALD, Kelly and Francis CARO. 2014. "An Overview of Age-friendly Cities and Communities Around the World." Journal of Aging \& Social Policy 26: 1-18.

GERRITSEN, J. C., E. W. WOLFFENSPERGER and W. J. A. van den HEUVEL, 1990. "Rural-urban Differences in the Utilization of Care by the Elderly." Journal of Cross-Cultural Gerontology 5(2): 131-147.

GIERYN, Thomas. 2000. “A Space for Place in Sociology.” Annual Review of Sociology 26(1): 463-469.

GOBBENS, Robert and Marcel VAN ASSEN. 2018. "Associations of Environmental Factors with Quality of Life in Older Adults." The Gerontologist 58(1): 101-110.

GOLANT, Stephen. 2014. “Age-Friendly Communities: Are We Expecting Too Much?” IRPP Insight, February, 5.

IFA (International Federation on Aging). 2015. Age - Friendly Cities and Communities - "Creating Enabling Environments" (The Conference Plenary Panel Abstract). Retrieved September 10, 2015 (http://www.ifa-fiv.org/wp-content/uploads/2015/06/Day-2-Plenary-Panel-Abstract.pdf).

KANO, Megumi, Paul ROSENBERG and Sean DALTON. 2018. "A Global Pilot Study of Age-Friendly City Indicators.” Social Indicators Research 138(3): 1205-1227.

KEATING, Norah, Jacquie EALES and Judith PHILLIPS. 2013. "Age-Friendly Rural Communities: Conceptualizing 'Best-Fit'.” Canadian Journal on Aging 32(4): 319-332.

KENDIG, Hal. 2003. "Directions in Environmental Gerontology: A Multidisciplinary Field." The Gerontologist 43(5): 611-615.

KLIMEŠOVÁ, Blanka. 2018. "Komunitní plánování veřejného prostoru se seniory.” [Community Planning of the Public Space with the Elderly]. Pražské matky/Život 90. Retrieved October 13, 2018 (https://drive.google.com/drive/folders/1gV8jgEWmVymQ9F3JPnqFecVdLBXoIujm).

KULCSÁR, László and David BROWN. 2017. "Population Ageing in Eastern Europe: Toward a Coupled Micro-Macro Framework.” Regional Statistics 7(1): 115-134. 
LEVASSEUR, Mélanie, Mélissa GÉNÉREUX, Jean-Francois BRUNEAU, Alain VANASSE, Éric CHABOT, Claude BEAULAC and Marie-Michéle BÉDARD. 2015. "Importance of Proximity to Resources, Social Support, Transportation and Neighbourhood Security for Mobility and Social Participation in Older Adults: Results from a Scoping Study." BMC Public Health 15(1): 503.

LINDENBERG, Jolanta and Rudi WESTENDORP. 2015. "Overcoming Old in Age-Friendliness." Journal of Social Work Practice 29(1): 85-98.

LUI, Chi-Wai, Jo-Anne EVERINGHAM, Jeni WARBURTON, Michael CUTHILL and Hellen BARTLETT. 2009. "What Makes a Community Age-friendly: A Review of International Literature." Australasian Journal on Ageing 28(3): 116-121.

MAJEROVÁ, Věra. et al. 2005. “Český venkov 2004: Život mladých a starých lidí.” [The Czech Countryside: The Lives of Young People and Older Adults]. Prague: Czech University of Life Sciences, Faculty of Economics and Management.

MENEC, Verena and Scott NOWICKI. 2014. "Examining the Relationship between Communities' 'Age-friendliness' and Life Satisfaction and Self-perceived Health in Rural Manitoba, Canada." Rural and Remote Health 14: 2594.

MENEC, Verena, Louise HUTTON and Nancy NEWALL. 2015. "How 'Age-friendly' are Rural Communities and What Community Characteristics are Related to Age-friendliness? The Case of Rural Manitoba, Canada." Ageing and Society 35(1): 203-223.

MENEC, Verena, Nancy NEWALL and Scott NOWICKI. 2016. “Assessing Communities' Age-Friendliness: How Congruent Are Subjective Versus Objective Assessments?" Journal of Applied Gerontology 35(5): 649-665.

MOULAERT, Thibauld and Susanne GARON, eds. 2016. Age-Friendly Cities and Communities in International Comparison: Political Lessons, Scientific Avenues and Democratic Issues. New York: Springer.

PERLÍN, Radim (nd.). "Venkov, typologie venkovského prostoru." [A Rural Area, a Typology of Rural Space]. Czech Ministry of the Interior. Accessed February 1, 2018 (www.mvcr.cz/soubor/perlin-pdf).

PERLÍN, Radim, Silvie KUČEROVÁ and Zdeněk KUČERA. 2010. "Typologie venkovského prostoru Česka.” [A Typology of Rural Space in Czechia]. Geografie 115(2): 161-187.

PETR, Ondřej. 2015. Regional Differentiation of Demographic Development of Rural Areas of the Czech Republic. PhD disertation. Brno: Masaryk University, Faculty of Economics and Administration.

PETROVÁ KAFKOVÁ, Marcela, Lucie VIDOVIĆOVÁ and Petr WIJA. 2018. "Older Adults and Civic Engagement in Rural Areas of the Czech Republic.” European Countryside 10(2): 247-262.

PLÜSCHKE-ALTOF, Bianca. 2016. "Rural as Periphery Per Se? Unravelling the Discursive Node." Sociální studia/Social Studies 13(2): 11-28.

POSPĚCH, Pavel. et al. 2014. Vynalézání venkova v ČR po roce 1989. [Re-inventing the Rural in the post-1989 Czech Republic]. Brno: CDK.

POSPĚCH, Pavel, Miloslav DELÍN and Daniela SPĚŠNÁ. 2009. "Quality of Life in Czech Rural Areas." Agriculture Economics 55(6): 284-295.

SPINA, John and Verena MENEC. 2015. "What Community Characteristics Help or Hinder Rural Communities in Becoming Age-Friendly? Perspectives from a Canadian Prairie Province." Journal of Applied Gerontology 34(4): 444-464.

STEELS, Stephanie. 2015. "Key Characteristics of Age-friendly Cities and Communities: A Review." Cities 47: 45-52.

STONAWSKÁ, Kateřina and Antonín VAISHAR. 2018. "Differentiation and Typology of the Moravian Countryside." European Countryside 10(1): 127-140.

UNECE Policy Brief on Ageing No. 18 “Older Persons in Rural and Remote Areas." 2017. Retrieved August 21, 2018 (https://www.unece.org/fileadmin/DAM/pau/age/Policy_briefs/ECE-WG1-25.pdf).

VAISHAR, Antonín, Lucie VIDOVIĆOVÁ and Elisabete FIGUEIREDO. 2018. "Quality of Rural Life." European Countryside 10(2): 180-190. 
VIDOVIĆOVÁ, Lucie. 2017. "How Age-Friendly are Cities? Measuring Age-Friendliness with a Composite Index." Pp. 277-297 in Emerging Trends in the Development and Application of Composite Indicator, edited by Veljko JEREMIC, Zoran RADOJICIC and Marina DOBROTA. Hershey, PA: IGI Global.

VIDOVIĆOVÁ, Lucie, Lucie GALČANOVÁ, Marcela PETROVÁ KAFKOVÁ and Dana SÝKOROVÁ. 2013. Stárí ve městě, město v životě seniorü [Ageing in the City, City in the Lives of Older Adults]. Prague: Sociologické nakladatelství.

WAHL, Hans-Werner and Gerald WEISMAN. 2003. "Environmental Gerontology at the Beginning of the New Millennium: Reflections on its Historical, Empirical, and Theoretical Development." The Gerontologist 43(5): 616-627.

WALSH, Kieran. 2017. “Constructions of Old-age Exclusion: In Place and Shaped by Place.” Pp. 252-266 in Geographical Gerontology: Perspectives, Concepts, Approaches, edited by Mark W. SKINNER, Gavin J. ANDREWS and Malcolm P. CUTCHIN. Abingdon: Routledge.

WARTH, Lisa. 2016. "The WHO Global Network of Age-Friendly Cities and Communities: Origins, Developments and Challenges." Pp 37-46 in Age-Friendly Cities and Communities in International Comparison. Political Lessons, Scientific Avenues and Democratic Issues, edited by Thibault MOULAERT and Susanne GERON. New York: Springer.

WEBBER, Sandra, Michelle PORTER and Verena MENEC. 2010. "Mobility in Older Adults: A Comprehensive Framework." The Gerontologist 50(4): 443-450.

WHO. 2002. "Active Ageing: A Policy Framework." Retrieved August 21, 2018 (http://www.who.int/ ageing/publications/active ageing/en/).

WHO. 2007. Global Age-friendly Cities: A Guide. Retrieved September 10, 2015 (http://www.who.int/ ageing/publications/Global_age_friendly_cities_Guide_English.pdf).

WHO. 2015. "Measuring the Age-friendliness of Cities: A Guide to Using Core Indicators." (http://www. who.int/kobe_centre/publications/AFC_guide/en/).

WIGHT, Richard, Michelle KO and Carol ANESHENSEL. 2011. "Urban Neighbourhoods and Depressive Symptoms in Late Middle Age." Research on Aging 33(1): 28-50.

WILES, Janine, Annette LEIBING, Nancy GUBERMAN, Jeanne REEVE and Ruth ALLEN. 2012. “The Meaning of 'Aging in Place' to Older People." The Gerontologist 52(3): 357-366.

WONG, Moses, Pui HING CHAU, Francis CHEUNG, David PHILLIPS and Jean WOO. 2015. "Comparing the Age-Friendliness of Different Neighbourhoods Using District Surveys: An Example from Hong Kong." PloS One 10(7).

ZAIDI, Asghar and David STANTON. 2015. “Active Ageing Index 2014: Analytical Report.” UNECE/ European Commission. Retrieved October 13, 2018 (https://statswiki.unece.org/download/ attachments/76287849/AAI\%20Report\%20LOW\%20RES.PDF?version=2\&modificationDate=14 $33927681725 \& a \mathrm{api}=\mathrm{v} 2$ ).

\section{Author}

Lucie Vidovićová is a sociologist, working at the Office for Population Study, Faculty of Social Studies, Masaryk University. She also serves as a vice president of the research committee on ageing at the International Sociological Association (ISA RC 11) and as a co-leader of the working group on the community and spatial social exclusion at the EU COST ROSEnet project "Reducing Old-Age Social Exclusion: Collaborations in Research and Policy" (CA15122). She runs the web pages www.ageismus.cz and http://starnuti.fss.muni.cz.

Contact: lucie.vidovic@seznam.cz 